\title{
NBSIR 75-923
}

\section{Corrosion of Metallic Piping on Military Bases - A Survey}

Paul Wencil Brown

and

James R. Clifton

Institute for Applied Technology

National Bureau of Standards

Washington, D. C. 20234

November 1975

Final

\section{Prepared for}

Office of the Chief of Engineers, U.S. Army

Washington, D. C. 20314

Directorate of Civil Engineering, U.S. Air Force

Washington, D. C. 20330

Naval Facilities Engineering Command, U.S. Navy

Alexandria, Va. 22332 



\section{CORROSION OF METALLIC PIPING ON MILITARY BASES - A SURVEY}

Paul Wencil Brown

and

James R. Clifton

Institute for Applied Technology

National Bureau of Standards

Washington, D. C. 20234

November 1975

Final

Prepared for

Office of the Chief of Engineers, U.S. Army

Washington, D. C. 20314

Directorate of Civil Engineering, U.S. Air Force

Washington, D. C. 20330

Naval Facilities Engineering Command, U.S. Navy

Alexandria, Va. 22332

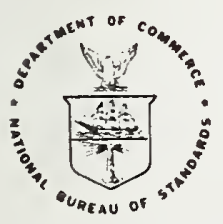

U.S. DEPARTMENT OF COMMERCE, Rogers C.B. Morton, Secretary James A. Baker, III, Under Secretary

Dr. Betsy Ancker-Johnson. Assistant Secretary for Science and Technology

NATIONAL BUREAU OF STANDARDS, Ernest Ambler, Acting Director 



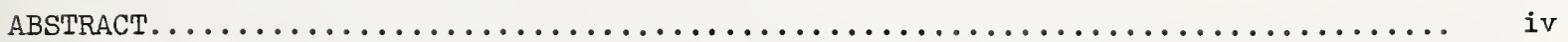

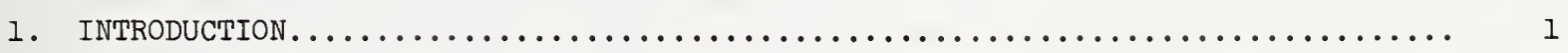

2. REVIEW OF THE CORROSION SURVEYS $\ldots \ldots \ldots \ldots \ldots \ldots \ldots \ldots \ldots \ldots \ldots \ldots \ldots \ldots \ldots \ldots \ldots \ldots \ldots \ldots$

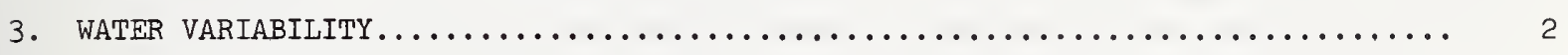

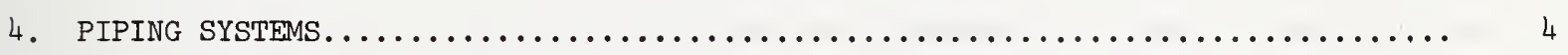

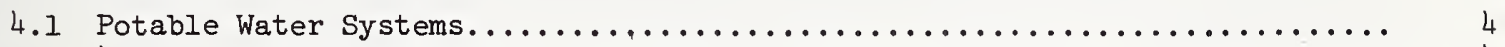

4.1.1 Corrosion Evaluation of Water Systems..................... 4

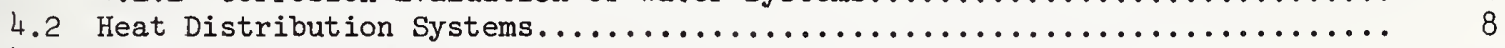

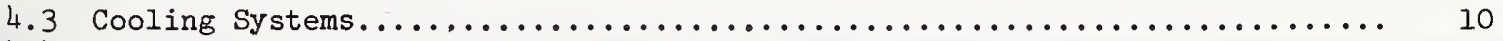

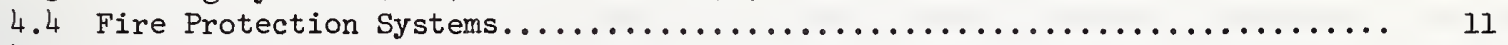

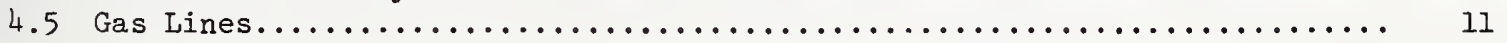

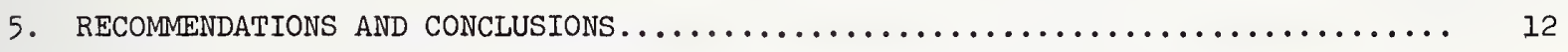

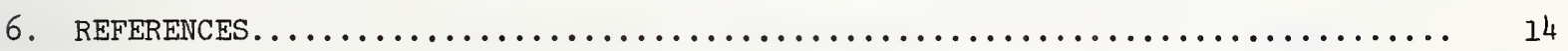




\section{ABSTRACT}

The results of surveys of the extent of corrosion of metallic piping systems at selected military installations have been analyzed. Potable water, fire protection, heat distribution, cooling, and natural gas distribution systems are included in these surveys. The corrosion evaluation techniques used in these surveys and the types of protection applied are discussed. General recommendations regarding continuation and extension of these surveys are given.

Keywords: Corrosion; corrosion control; metallic piping; nondestructive evaluation; survey; water hardness. 


\section{INTRODUCTION}

The corrosion of metallic piping systems is a nationwide problem resulting in interrupted operations and expensive repairs. The costs associated with corrosion-related failures have been estimated to be 22 billion dollars annually. The extent of piping corrosion problems at military facilities, while likewise presumed to be high, has not been well identified. This indicates the need to characterize the type and frequency of corrosion failures encountered at military facilities in order to more effectively evaluate and recommend corrosion control procedures.

Accordingly, as part of an on-going corrosion survey program, the metallic piping systems of selected Air Force installations have been inspected by Air Force personnel to determine the extent of corrosion. Selected surveys have been reviewed and form the basis for the present report in which the most common corrosion problems are identified and discussed. Recommendations of methods to minimize the corrosion of piping systems and methods to improve the corrosion inspections are also given.

This study was carried out with Tri-Service support.

\section{REVIEW OF THE CORROSION SURVEYS}

The corrosion surveys [1-11], conducted by military personnel, were for the most part limited to the following fluid transportation systems:
1) Potable water systems
2) Fire protection systems
3) Natural gas lines
4) Heat distribution systems
5) Cooling systems. 
Corrosion problems in sewage disposal systems and in systems designed to carry liquid fuel or highly corrosive materials were not considered. With the exception of natural gas lines, both interior and exterior surfaces were examined for corrosion. The sites included in this survey are:
1) Goodfellow AFB, Texas
2) McClellen AFB, California
3) Homestead AFB, Florida
4) Robbins AFB, Georgia
5) Altus AFB, Oklahoma
6) Richards-Gebaur AFB, Missouri
7) Elgin AFB, Florida
8) Tinker AFB, Oklahoma
9) Andrews AFB, Maryland
10) F.E. Warren AFB, Wyoming
11) Loring AFB, Maine.

The data analyzed in the following sections have been taken from these surveys.

\section{WATER VARIABILITY}

Water samples from the sites included in the survey were chemically analyzed. These analyses revealed that the nature of the water varied from hard and scale-forming to soft and corrosive. The range of the properties of the water is indicated in table 1. Hard water contains dissolved alkaline materials such as calcium bicarbonate which may inhibit but also tend to deposit on the interior walls of piping systems. Hard water is usually obtained from wells and its high mineral content is the result of mineral extraction during underground flow. Protective films of chalky rust, a mixture of calcium carbonate and iron oxide, may be formed on ferrous piping transporting hard water in the presence of calcium bicarbonate if the $\mathrm{CO}_{2}$ content of the water is limited to the amount required for its stabilization [12]. In this case, a very small pH rise will suffice to supersaturate the water near the metal with calcium carbonate. However, protection is obtained only 
if sufficient oxygen is available to oxidize ferrous compounds to the less soluble ferric compounds. Solid material that precipitates at points remote from pipe walls does not form an adhering protective coating. Soft water may also contain dissolved minerals, but their concentrations are usually lower. Soft water is generally obtained from sources at or near the earth's surface and is corrosive due to the presence of carbonic acid. Carbonic acid may be formed by the dissolution of atmospheric $\mathrm{CO}_{2}$ or from $\mathrm{CO}_{2}$ generated by rotting vegetation. Cascading of such water is helpful in minimizing corrosion [13]. Cascading allows $\mathrm{CO}_{2}$ gas to escape shifting the following reaction to the right:

$$
\mathrm{H}_{2} \mathrm{CO}_{3} \rightleftharpoons \mathrm{H}_{2} \mathrm{O}+\mathrm{CO}_{2} \text {. }
$$

$\mathrm{CaCO}_{3}$ addition may or may not be of value in the treatment of aggressive water. The Langlier saturation index [14] is commonly used to characterize the aggressiveness of $\mathrm{CO}_{2}$ in water and its value indicates the difference between the initial pH value and that after treatment with $\mathrm{CaCO}_{3}$. A negative value indicates the inability of water to develop a protective film.

TABLE 1

Range of Properties of Potable Water at Military Facilities $1-11$

\begin{tabular}{lcc}
\hline Analysis & Maximum & Minimum \\
\hline pH & 9.9 & 6.6 \\
Total Alkalinity (1) & 265 & 30 \\
Ca Hardness & 355 & 40 \\
Total Hardness (1) & 205 & 45 \\
Dissolved Solids (2) & 950 & 63 \\
Conductivity (umho/cm) & 2300 & 160 \\
Langlier Index & +2.3 & -1.5 \\
Dissolved Oxygen (ppm) & 9.8 & 1.0 \\
\hline
\end{tabular}

(1) Expressed as equivalent ppm $\mathrm{CaCO}_{3}$.

(2) Calculated from conductance reading. 


\section{PIPING SYSTEMS}

\subsection{Potable Water Systems}

The sites examined in this survey are geographically widely dispersed including various soil and climatic conditions, figure 1. The variabilities in the water supplied to these sites may therefore be considered reasonably representative of those encountered at most military installations within the continental U.S.

\subsubsection{Corrosion Evaluation of Water Systems}

Radiography was the technique primarily employed in the evaluation of the severity of both corrosion and scale formation in undisturbed building service water lines. In some cases, however, excavations were carried out and then radiographic analyses performed. In one instance, an electrical potential survey of a water main was performed [10] because this main had leaked in the past. The presence of corrosion cells was indicated by the variation in measured potentials. Accordingly, a cathodic protection current requirement measurement was made and indicated a very large protection current requirement of 230 amps. Failures of this type may be expected when inadequate attention is directed toward factors such as soil conditions. Soil resistivity measurements, also a part of this survey, were performed at this base. Values as low as $1550 \Omega-\mathrm{cm}$ were measured, indicative of an environment in which corrosion of an unprotected ferrous structure can be expected (table 2). Specifically, soil resistivities less than $10,000 \Omega$-cm are considered corrosive to steel, while those less than $5,000 \Omega-\mathrm{cm}$ corrosive to cast iron [16-17].

TABLE 2 [15]

Soil Corrosivity vs Resistivity

Resistivity, $\Omega-\mathrm{cm}$

Below 500

$500-100$

$1000-2000$

2000-10,000

Above 10,000
Corrosivity

Very corrosive

Corrosive

Moderately corrosive

Mildly corrosive

Progressively less

corrosive 


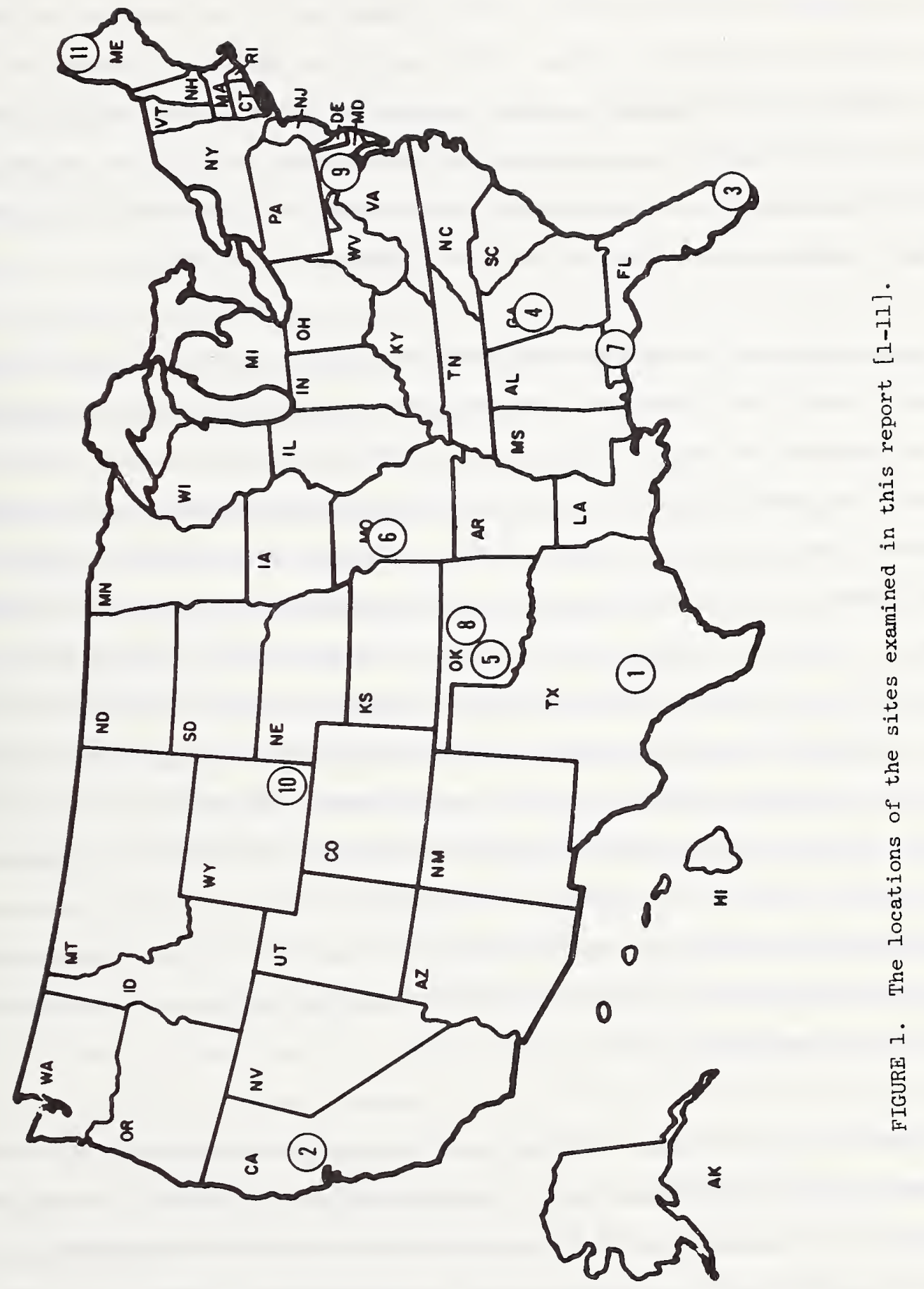


Soil resistivities along actual and proposed routes for underground metallic pipe should be routinely measured. These measurements are useful in the location of low resistivity areas, hot spots, to determine proper anode placement and in the estimation of external protective coating requirements for pipes. Soil resistivity measurements should be carried out at different times throughout the year in order to take account of the soil moisture content as this will affect protection current requirements. In addition, remeasurement should be carried out on a routine basis. This is especially important in areas where a build-up of hygroscopic electrolytes, such as deicing salts, may occur.

While numerous soil evaluation techniques exist [18], the measurement of soil resistivity is the most widely used criterion in the assessment of soil corrosivity. Investigations have both supported the value of this criterion [19] and cautioned against its use [20-21.]. However, it is generally agreed that resistivity measurement provides the best single indication of the corrosivity of soil. These measurements may be made in 2 ways. The Wenner 4 probe method [22] involves the measurement of the potential between 2 probes driven into the ground. Current is supplied by an additional 2 probes. This technique allows the measurements to be taken at the site without disturbing the soil. The soil box method [23] requires obtaining a core sample from the soil and measuring its resistance directly. The advantages of the Wenner method lie in its ease and speed. In addition, the resistance of a large soil volume is measured thereby improving accuracy. The principal advantage of the soil box method is that it is possible to intentionally vary the moisture content of the soil. Although the Wenner method was used exclusively in the soil resistivity measurements included in this survey, the soil box method is of value in testing soils in areas where substantial annual moisture variations occur.

In general, the water lines examined in this survey are in good condition having slight to moderate amounts of pitting or scale. When evaluating the degree of scale deposition on building service water lines, both hot and cold water lines should be examined in the future inspections, particularly in areas where hard, untreated water is used. A greater degree of scale build-up occurs in hot water lines and, especially in water heaters due to water evaporation and $\mathrm{CaCO}_{3}$ precipitation. However, overall indications were that the levels of water treatment were adequate. Radiographic, ultrasonic, or other appropriate corrosion 
detection measurements should be carried out on a routine basis, preferably at representative and fixed points, to determine the deterioration rates and hence the projected lifetimes of these systems.

One technique upon which undue reliance seems to be placed is that of electrical potential measurement. Measurements of this type, if properly conducted, may give information as to the thermodynamic probability of corrosion taking place. These measurements, however, provide no kinetic or corrosion rate information. The traditional assumption that a potential of -0.85 volt between buried ferrous structure and a $\mathrm{Cu}-\mathrm{CuSO}_{4}$ electrode is indicative of adequate cathodic protection is not necessarily valid. Voltage gradients, or the presence of junction potentials may act to invalidate this assumption [24].

Linear polarization is a technique by which the dynamics of the corrosion process may be readily determined [25-26]. This technique has the advantage of allowing in-situ corrosion rate measurements. In addition, the instrumentation may be remote from the corroding body. An electrode may be inserted in the wall of a buried pipe either during installation or after excavation. By establishing a test station at the ground surface after backfilling, corrosion rate measurements can be carried out on a routine basis. Disadvantages in this method lie in the expense of the electrodes and instrumentation and in that it is not possible to ascertain the type of corrosive attack, such as general, pitting, etc., by this technique.

Radiography probably provides the most powerful nondestructive evaluation technique by which the extent of corrosion may be ascertained because it provides information both as to the type and degree of deterioration. However, determination of the degree of general corrosion is difficult unless a reference point of known thickness is available [27]. The major limitation of radiography lies in the requirement of access to both sides of the structure undergoing inspection. Ultrasonics and eddy current techniques [28-29] may also be used to detect wall thickness discontinuities and corrosion pitting and are well suited for absolute thickness measurements. Although these techniques are not useful in the detection of scale and sediment deposits, they are useful corrosion assessment techniques where access is limited as in the building service lines. 


\subsection{Heat Distribution Systems}

Of all systems included in this survey, heat distribution systems, due to their complexity and their operation at elevated temperatures, are probably the most susceptible to corrosion failure. The results of this survey indicate that a large part of this vulnerability lies in the fact that, while the proper corrosion control measures exist, they have either not been instituted or have been largely ignored.

The survey of the heat distribution systems consisted primarily of chemical analyses of boiler water and condensate samples and the radiographic examination of the steam and condensate return lines. Analyses of boiler feed water and ultrasonic thickness measurements were carried out in some cases. Radiographic examination of the steam lines of the boiler systems included in this survey indicated them to be free of serious scale and pitting in most instances. The corrosion observed in the condensate return lines, however, may be characterized as moderate to severe. This indicates that the water treatment programs are adequate to protect the steam lines but in most cases do not afford sufficient protection to the condensate return systems.

It was noted that improper procedures regarding the addition of make-up water were being followed at several of the sites. Water softening units were either being by-passed or exhausted zeolite exchangers were not reactivated. In addition, de-aeration units were found to be operating ineffectively. The introduction of oxygen and $\mathrm{CO}_{2}$ into boiling systems may result in severe pitting and channeling in condensate return lines. The addition of volatile inhibiting amines may be used to neutralize absorbed $\mathrm{CO}_{2} \cdot \mathrm{Care} \mathrm{must}$ be taken in doing this, however, because these compounds tend to accelerate the corrosion of any nonferrous metals present in the system. Furthermore, it is difficult to estimate the concentration of these amines in the areas which are remote from the boiler. While there are a number of proprietary corrosion inhibiting compounds marketed, their use is not recommended. Uncertainties, as to their effectiveness and their compatibility with other additives, combined with the inability to adjust the relative amounts of their constituents weigh heavily against the use of proprietary inhibitors. 
One instance was reported [5] where a ferrous condensate return line was replaced by a section of continuous filament fiberglass reinforced plastic pipe. Apparently, the use of this material is under consideration by the military for inclusion in the various service manuals. However, further investigation may be warranted prior to the acceptance of this material as a substitute for metallic pipe in boiler systems since degradation due to inhibitor attack may result.

Chemical analyses of both the boiler water and the condensate were carried out in most cases. The extremes of these analyses are listed in table 3. The variability of the analyses listed in this table and their deviations from recommended values [30] is indicative of the inadequacy of the treatment programs. Generally, the pH of the condensate was lower than that of the boiler water although in one boiler system it was actually higher. Substantial concentrations of dissolved solids, oxygen, and $\mathrm{CO}_{2}$ were observed. Although most steam lines were reported to be scale free, dissolved solid precipitation was noted to have caused sediment build-up and flow restriction in at least one system.

Boilers are also susceptible to corrosion when idle. If the dry lay up method is used, sedimentary deposits, due to their tendency to retain moisture may, during off-season shut down periods, lead to accelerated corrosion. Even proper drainage after shut down will not alleviate this problem. The presence of condensed moisture droplets, because of incomplete drying, may also result in pitting due to the introduction of oxygen or $\mathrm{CO}_{2}$ into the system as the pressure is dropped. The inleakage of feed water to a dry boiler system may lead to corrosion by a similar mechanism. Complete drying by the addition of a suitable drying agent, such as quicklime, or the circulation of dry air under positive pressure is recommended Bo 1 .

The wet lay up method, that is filling the boiler system with treated water, may be used as well. However, deaerated water should be used to avoid pitting corrosion. Maintenance of proper $\mathrm{pH}$ through $\mathrm{NaOH}$ or $\mathrm{Na}_{2} \mathrm{SO}_{3}$ addition should be carried out by continuous feeding as this will minimize concentration gradients and hence corrosion cells. 
TABLE 3

Analyses of Boiler Water and Condensate

\begin{tabular}{|c|c|c|c|c|c|c|}
\hline \multirow[b]{2}{*}{ Analysis } & \multirow{2}{*}{$\frac{\text { Boiler }}{\text { Max }}$} & \multirow{2}{*}{$\frac{\text { Water }}{\text { Min }}$} & \multirow{2}{*}{$\begin{array}{c}\text { Recommended } \\
{[30]}\end{array}$} & \multicolumn{2}{|c|}{ Condensate } & \multirow{2}{*}{$\begin{array}{c}\text { Recommended } \\
{[30]}\end{array}$} \\
\hline & & & & $\overline{\operatorname{Max}}$ & Min & \\
\hline $\mathrm{pH}$ & 12 & 8 & $10.5-11.5$ & 8.3 & 5.3 & $7.5-8.5$ \\
\hline $\begin{array}{l}\text { Ca Hardness* } \\
(\mu \mathrm{mho} / \mathrm{cm})\end{array}$ & 120 & 0 & $\min$. & - & - & - \\
\hline $\begin{array}{l}\text { Dissolved Solids } \\
\text { (ppm) }\end{array}$ & 10,000 & 765 & $1000-4000$ & 780 & 2 & $\min$. \\
\hline $\begin{array}{l}\text { Dissolved Oxygen* } \\
\text { (ppm) }\end{array}$ & 6.8 & 0 & $I \mathrm{ppm}$ & 5.6 & 0 & $1 \mathrm{ppm}$ \\
\hline $\mathrm{CO}_{2}(\mathrm{ppm})$ & - & - & min. & 20 & 0 & min. \\
\hline Iron (ppm) & - & - & - & 2.5 & 0 & $\min$. \\
\hline
\end{tabular}

\section{*feed water \\ 4.3 Cooling Systems}

The cooling systems survey was limited to radiographic analyses of cooling water lines and chemical analyses of cooling water samples. The cooling systems at two of the sites were not inspected and the examination of several of the others were rather restricted, apparently because maintenance is carried out on a contract basis.

Radiographic analyses were carried out at six sites. These analyses indicated the presence of slight to moderate amounts of scale with a small amount of pitting. Visual inspection of the cooling lines revealed that moisture condensation had saturated the thermal insulation in several cases. In addition to increasing the probability of corrosion since cathodic protection cannot be applied to cooling lines, the presence of moisture will greatly reduce thermal barrier effectiveness.

The chemical analyses of the cooling water revealed both the pH values and the concentrations of dissolved solids to be above acceptable limits in almost all instances. The extremes of these analyses are listed in table 4. Concentrations of dissolved solids and $\mathrm{pH}$ values in the ranges indicated in table 4 are conducive both to scale formation and algae growth. Scale formation and algae growth not only reduce cooling efficiency but may also result in flow restriction or blockage. Fortunately, control of algae and scale is easily 
accomplished by $\mathrm{pH}$ control. Maintaining $\mathrm{pH}$ values in the recommended range along with the addition of small amounts of algicide, sodium hexametaphosphate complexer and other inhibitors should afford adequate control. The phosphate inhibitor will complex $\mathrm{CaCO}_{3}$ and also inhibit corrosion if the proper concentration of dissolved solids is maintained. Other types of corrosion inhibitors may be added to cooling systems although chromates should be avoided due to their toxicity.

TABLE 4

Analyses of Cooling Tower Water

\begin{tabular}{lrrr}
\hline Analysis & \multicolumn{2}{c}{ Observed } & Max \\
\hline pH & & 8.1 & $6.5-7.5$ \\
Dissolved solids (ppm) & 9.7 & 180 & $600-1000$ \\
Chromates (ppm) & 12000 & 0 & 0 \\
\hline
\end{tabular}

\subsection{Fire Protection Systems}

The condition of the fire protection systems appears to be comparable to that of the potable water systems. However, the surveys of several of the sites indicated that build-up. of substantial amounts of scale and sediment had occurred in the piping. This is a potentially serious problem since this could result in the clogging of sprinkler heads. Flow testing with flushing on a routine basis should be adequate to alleviate this condition. Sediment build-up can present serious problems even beyond that of flow restriction. For example, sediment build-up across dielectric joints may provide high conductivity paths across these joints and thereby allow galvanic corrosion. The measurement of the electrical resistivities across these joints should give a reasonable indication of the severity of the problem.

\subsection{Gas Lines}

The gas lines inspected in this survey, when cathodically protected, were for the most part in good condition. A section of a cast iron gas main at one of the sites was found to be unprotected [8]. Cathodic protection was unfeasible in this instance because this section 
of pipe was not electrically continuous. It was recommended by the survey team that the economic feasibility of excavating this section, electrically connecting the joints, and applying cathodic protection be investigated. After the expenses of remedial measures of this type are evaluated against those of premature replacement, appropriate action should be taken.

One line which was cathodically protected had failed [5]. This failure was attributed to the presence of holidays in the pipe coating. Because the coating was poorly bonded to the pipe, the presence of holidays allowed moisture to migrate into the areas between the coating and the pipe wall. These areas were not cathodically protected, because the coating was an electrical insulator, and a corrosion failure resulted.

Soil resistivity has an important impact on the degree of cathodic protection. Seasonal moisture variations, for example, may cause a piping system to become either under- or over-protected. Underprotection may lead to direct corrosion attack while overprotection can result in coating damage. If excess potential is applied to a coated structure, free hydrogen will be evolved. Hydrogen gas bubbles may coalesce and exert pressure sufficient to cause disbonding and rupture of a coating.

The detection of holidays in buried pipe coatings should be carried out prior to the initial backfilling and after any excavation as a matter of routine. In addition to visual and electrical inspection for holidays per se, coating thickness and moisture content detectors exist which may be used in the evaluation of coating quality and durability.

\section{RECOMMENDATIONS AND CONCLUSIONS}

1) The surveys discussed in this report provide an excellent starting point for the analysis of the type, frequency, and severity of the corrosion problems encountered. However, greater specificity regarding materials used, age at failure, and failure characterization would be helpful.

2) A survey program of this type should be instituted and carried out on annual or semi-annual basis. 
3) Sufficient data should be collected and then be used to develop criteria to define adequate performance levels for the various systems studied. Comparative analyses of protection system performance, piping system life prediction, and performance criteria for materials selection may then be evaluated by consistent deterioration rate observation.

4) The inclusion of corrosion failure cost analyses, such as the Corrosion Costs Survey, Chanute AFB [31], would also be of berefit in a survey program. Input of this type would provide a basis for the prediction of funding and manpower requirements attributable to each class of corrosion fallure and would indicate areas in which additional research and development should be carried out. 


\section{REFERENCES}

1. Corrosion Analysis Survey Report, Goodfellow AFB, Texas, December 1972.

2. Corrosion Analysis Survey Report, McClellen AFB, California, October 1973.

3. Corrosion Analysis Survey Report, Homestead AFB, Florida, November 1973.

4. Corrosion Analysis Survey Report, Robbins AFB, Georgia, February-March 1973.

5. Corrosion Analysis Survey Report, Altus AFB, Oklahoma, August-September 1973.

6. Corrosion Analysis Survey Report, Richards-Gebaur AFB, Missouri, August-September 1973.

7. Corrosion Analysis Survey Report, Eglin AFB, Florida, January-February 1974.

8. Corrosion Analysis Survey Report, Tinker AFB, Oklahoma, October 1972.

9. Corrosion Analysis Survey Report, Andrews AFB, Maryland, January-February 1973.

10. Corrosion Analysis Survey Report, F. E. Warren AFB, Wyoming, July-August 1973.

11. Corrosion Analysis Survey Report, Loring AFB, Maine, May-June 1973.

12. U. R. Evans, The Corrosion and Oxidation of Metals, Edward Arnold, London 1960, pp. $160-3$.

13. E. L. Steatfield, J. Soc. Chem. Ind. 58, 313 (1939).

14. M. Pourbaix, Lectures on Electrochemical Corrosion, Plenum Press, New York, 1973, p. 75.

15. A. W. Peabody in: NACE Basic Corrosion Course, 1971, pp. 5-17. 
16. M. Romanoff, Jnl. AWWA 56, 1129 (1964).

17. J. H. Fitzgerald, Jnl. AWWA 60, 882 (1968).

18. E. Escalante and W. P. Iverson, Unpublished research.

19. J. D. Palmer, Matls. Performance 13, 41 (1974).

20. E. Schaschl and E. A. Marsh, Materials Protection 2, 424 (1963).

21. N. D. Tomashov and Y. N. Mikhailovsky, Corrosion 15, 79t (1959).

22. F. Wenner, NBS Bull. 12, 469 (1916).

23. Soil Survey Manual, USDA Handbook 18, 343 (1951).

24. J. J. Meany, Jr., Proc. 17th Annual Underground Corrosion Short Course, Engr. Expt. Station Bull. 106, West Va. Univ., p. 596 (1972).

25. W. J. Schwerdtfeger, Materials Research and Stds. 10, 22 (1972).

26. R. I. Leroy, Corrosion 29, 272 (1973).

27. B. F. Peters, Matls. Evaluation 23, 129 (1965).

28. B. F. Peters, Engineering Journal 55, 20 (1972).

29. W. J. McGonnagle, Nondestructive Testing, Gordon \& Beach, 1966, New York, p. 346.

30. Boiler-Water-Treatment Manual for Federal-Plant Operators Handbook 5, 1951, Bureau of Mines, Dept. of Interior. 
31. R. Heidersbach and W. Mikucki, Letter Report M-89, Corrosion Costs Survey, Chanute AFB, April 1974. 
NBS.114A UEEV, I.7"1

\begin{tabular}{|c|c|c|c|}
\hline $\begin{array}{l}\text { U.S. DEPT. OF COMM. } \\
\text { BIBLIOGRAPHIC DATA } \\
\text { SHEET }\end{array}$ & 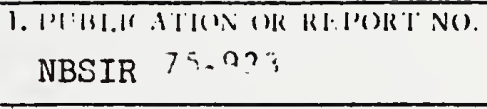 & $\begin{array}{l}\text { 2. (wiv's Accessitinn } \\
\text { No. }\end{array}$ & 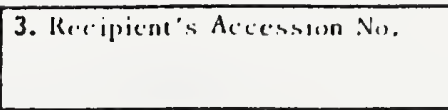 \\
\hline \multirow{2}{*}{\multicolumn{3}{|c|}{ 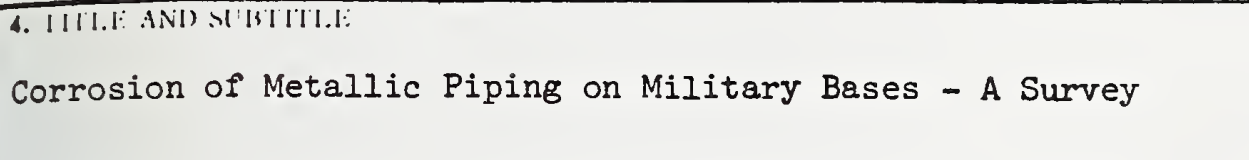 }} & $\begin{array}{l}\text { 5. P'ublicition Darc } \\
\text { November } 1975 \\
\end{array}$ \\
\hline & & & 6. Performing Organization Code \\
\hline \multirow{2}{*}{\multicolumn{3}{|c|}{$\begin{array}{l}\text { 7. AUTHOR(S) } \\
\text { PQul W. Brown and James R, Clifton } \\
\text { 9. PI:RIORMIN(i ORCIANILATION NAMI: ANI) ADIIRESS } \\
\text { NATIONAL BUREAU OF STANDARDS } \\
\text { DEPARTMENT OF COMMERCE } \\
\text { WASHINGTON, D.C. 20234 }\end{array}$}} & 8. Perfurming Organ. Repurt No. \\
\hline & & & $\begin{array}{l}\text { 10. Project/Task/Work Unit No. } \\
\text { 11. Contract/Grant No. }\end{array}$ \\
\hline \multicolumn{3}{|c|}{$\begin{array}{l}\text { 12. Sponsoring Organizirion N.mmc and (ompletc Address (Street, City, State, ZIP) } \\
\text { Office of Chief of Engineers, U.S. Army } \\
\text { Directorate of Civil Engineering, U.S. Air Force } \\
\text { Naval Facilities Engineering Command, U.S. Navy } \\
\text { Washington, D.C. }\end{array}$} & $\begin{array}{l}\text { 13. Type of Report \& Period } \\
\text { Covered } \\
\text { Final } \\
\text { 14. Spunsoring Agency Code }\end{array}$ \\
\hline
\end{tabular}

16. ARSTRACT (A 200-word or less tactual summary of most significant information. If document includes a significant bibliography or literature survey. mention it here.)

The results of surveys of the extent of corrosion of metallic piping systems at selected military installations have been analyzed. Potable water, fire protection, heat distribution, cooling, and natural gas distribution systems are included in these surveys. The corrosion evaluation techniques used in these surveys and the types of protection applied are discussed. General recommendations regarding continuation and extension of these surveys are given.

17. KEY W'ORDS (six to twelve entries; alphabefical order; capitalize only the first letter of the first key word unless a proper name; separated by semicolons)

Corrosion; corrosion control; metallic piping; nondestructive evaluation; survey; water hardness.

\section{Enlimited}

E For Orficial Distribution. Do Not Release to NTIS

L- Order From Sup. of Doc., U.S, Government Printing Office W'ashingtun, D.C. 20.102, 泣 C..1. No. (13

' $\boldsymbol{X}^{\prime}$ O, jer From Nactiunal Technical intormation Service (NTIS) springfield, Virginia 22151

\begin{tabular}{|l|c|}
\hline $\begin{array}{l}\text { 19. SECURITY CI.ASS } \\
\text { (TIIS REPURT) }\end{array}$ & 21. NO. OF P.AGES \\
UNCLASSIFIED & 20 \\
\hline $\begin{array}{l}\text { 20. SF(URITY (ALASI } \\
\text { (TIIS PANE) }\end{array}$ & 22. PrILE \\
UNCLASSHIH:D & $\$ .50$ \\
\hline
\end{tabular}




